\title{
Perancangan Alat Prush (Pembersih Busi Sederhana) Dengan Pendekatan Ergonomi Dan Value Engineering (Studi Kasus di UKM Bengkel Motor Koli Palembang)
}

\author{
Fransiskus Mario ${ }^{1}$ dan Heri Setiawan ${ }^{2}$ \\ ${ }^{1,2)}$ Fakultas Sains dan Teknologi, Program Studi Teknik Industri, Universitas Katolik Musi Charitas \\ Jl. Bangau No. 60 Palembang \\ Email: Mariiokjs8@gmail.com, heri_setiawan@ukmc.ac.id
}

\begin{abstract}
ABSTRAK
UKM Bengkel Motor Koli Palembang adalah UKM service motor. UKM ini melayani service ringan hingga service berat. Pada service ringan terdapat proses membersihkan busi dimana dalam satu hari mekanik bisa lebih dari 5 kali membersihkan busi, dengan alat pembersih busi yang lama, mekanik sering mengalami keluhan: busi terlepas, tangan mekanik merasa panas ketika memegang busi, dan percikan api mengenai mata mekanik ketika melakukan pembersihan bus. Selain itu, alat lama memiliki beberapa nilai ketidakergonomisan yang bisa dilihat pada ergonomics checklist berdasarkan wawancara kepada mekanik, sehingga diperlukan alat pembersih busi yang ergonomis untuk mengurangi keluhan mekanik. Oleh sebab itu dirancanglah alat pembersih busi baru "PRUSH" singkatan dari pembersih busi sederhana dengan pendekatan ergonomi dan value engineering. Konsep desain PRUSH adalah gabungan dari ragum silang 3 dan dinamo mesin jahit dengan dimensi tinggi ragum silang $10 \mathrm{~cm}$, lebar $20 \mathrm{~cm}$, tinggi tuas penggeser (maju/mundur) $5 \mathrm{~cm}$, tinggi tuas penggeser (kiri/kanan) $8 \mathrm{~cm}$, panjang tuas $8 \mathrm{~cm}$, tinggi penjepit busi $13 \mathrm{~cm}$, tinggi dinamo $13 \mathrm{~cm}$, lebar $22 \mathrm{~cm}$, diameter mata gerinda $13 \mathrm{~cm}$, dan alas $30 \mathrm{~cm}$ x $24 \mathrm{~cm}$. Harga pembuatan alat PRUSH Rp.480.000,00. Keunggulan alat PRUSH dibandingkan alat yang lama yaitu aman digunakan, tahan lama, mudah digunakan, nyaman, dan hemat daya listrik sehingga mengurangi keluhan. Daya listrik yang digunakan pada alat lama sebesar 375 watt telah menurun menjadi 120 watt.
\end{abstract}

Kata Kunci: Perancangan Alat, PRUSH, Ergonomi, Value Engineering.

\begin{abstract}
SME Koli Motorbike Repair Shop Palembang is an SME service motorbike. This SME serves light services to heavy service. In light services there is a process of cleaning spark plugs where in one day mechanics can more than 5 times clean spark plugs, with old spark plug cleaners, mechanics often experience complaints: spark plugs are released, mechanical hands feel hot when holding plugs, and sparks about mechanical eyes when do bus cleaning. In addition, the old tool has some non-ergonomic values that can be seen on the ergonomics checklist based on interviews with mechanics, so an ergonomic spark plug is needed to reduce mechanical complaints. Therefore a new spark plug cleaner is designed "PRUSH" stands for simple spark plug cleaner with an ergonomics and value engineering approach. The PRUSH design concept is a combination of crossing 3 vise and sewing machine dynamo with dimensions of crossing height of $10 \mathrm{~cm}$, width of $20 \mathrm{~cm}$, height of shifting lever (forward / backward) $5 \mathrm{~cm}$, height of slider lever (left I right) $8 \mathrm{~cm}$, lever length $8 \mathrm{~cm}$, spark plug clamp height $13 \mathrm{~cm}$, dynamo height $13 \mathrm{~cm}$, width $22 \mathrm{~cm}$, diameter of grinding eye $13 \mathrm{~cm}$, and base $30 \mathrm{~cm} \times 24 \mathrm{~cm}$. The price of making PRUSH tools is Rp.480,000.00. The advantages of the PRUSH tool compared to the old ones are that they are safe to use, durable, easy to use, comfortable, and save electricity, thus reducing complaints. The electrical power used in the old device of 375 watts has decreased to 120 watts.
\end{abstract}

Keywords: Tool Design, PRUSH, Ergonomics, Value Engineering.

\section{PENDAHULUAN}

Salah satu industri jasa yang ada di Palembang yang bergerak di bidang otomotif adalah UKM Bengkel Motor Koli Palembang. Jumlah karyawan saat ini sebanyak 2 orang termasuk pemilik UKM Bengkel ini.

UKM Bengkel Motor Koli Palembang merupakan bengkel yang bergerak pada bidang jasa perbaikan kendaraan motor. Beberapa proses pengerjaan di bengkel motor ini yaitu service ringan, dimana service ringan berupa membersihkan karburator, membersihkan busi, mengencangkan rante, mengganti oli, dan 
mengecek bagian lampu-lampu serta kelistrikan lainnya. Dimana service ringan ini dilakukan oleh mekanik sebanyak lebih dari 5 (lima) kali pada setiap harinya. Sedangkan service berat berupa mengganti sparepart mesin yang sudah rusak seperti mengganti connecting piston, mengganti kampas kopling dan kampas kopling ganda, mengganti piston, dan lain-lain. Dimana service berat ini dilakukan oleh mekanik sebanyak kurang dari 3 (tiga) kali dalam satu hari dan service berat tidak selalu dilakukan setiap harinya.

Pada penelitian ini, Pada UKM Bengkel Motor Koli Palembang terdapat proses kerja yang tidak nyaman ketika melakukan service ringan yaitu ketika membersihkan busi motor, dimana proses membersihkan busi tersebut menggunakan gerinda duduk kemudian busi dipegang dengan tangan. Terkadang mekanik yang melakukan proses tersebut merasa kurang nyaman karena panas ketika memegang busi, percikan dari gerinda tersebut mengenai tangan, hingga busi yang dipegang terlepas. Bahkan terdapat bengkel yang membersihkan busi hanya dengan mengamplas ujungnya saja, dimana proses terebut tidak membuat busi motor bersih dengan maksimal, masih terdapat kotoran bekas-bekas pembakaran pada busi tersebut.

Dari pengamatan pada beberapa bengkel tersebut, ditemukan bahwa tidak terdapat alat bantu untuk membersihkan busi melainkan gerinda duduk dengan harga yang relatif mahal berdasarkan merek dan diameter mata gerindanya yakni seharga Rp. 300.000,00 hingga Rp. 3.700.000,00 dengan daya listrik yang digunakan sebesar 375 watt ditambah dengan mata gerinda duduk yang kawat seharga Rp. 100.000,00. Selain itu terdapat alat pembersih busi yang lebih canggih namun dengan harga yang cukup mahal berkisar Rp. 2.400.000 hingga Rp. 6.400 .000 dengan daya listrik yang digunakan diatas 375 watt. Berdasarkan fenomena tersebut, perlu merancang serta mengembangkan produk alat pembersih busi sederhana dengan harga yang tidak terlalu mahal serta dapat meningkatkan kenyamanan ketika memegang busi agar tidak panas dan keamanan agar percikan api dan busi tidak terlepas dari genggaman mekanik dalam proses membersihkan busi. Karena pada proses membersihkan busi yang biasanya dilakukan mekanik dengan menggunakan gerinda duduk, mekanik sering mengalami keluhan seperti busi terlepas, percikan api mengenai muka atau mata mekanik, dan terasa panas ketika memegang busi.

Perancangan alat dilakukan dengan menggunakan metode Value Engingeering (VE). Metode Value Engingineering (VE) digunakan karena metode tersebut sangat cocok untuk memperhitungkan seberapa besar biaya yang dikeluarkan untuk merancang alat prush dan dapat melihat penilaian serta ide - ide dari masyarakat terutama mekanik motor terhadap alat baru ini. Metode Value Engingineering (VE) juga dapat menilai alternatif dari masing-masing material termasuk kelebihan dan kekurangan material yang akan digunakan untuk merancang alat.

Perancangan adalah suatu proses yang bertujuan untuk menganalisa, menilai dan memperbaiki serta menyusun suatu sistem, baik untuk sistem fisik maupun nonfisik yang optimum untuk waktu yang akan datang dengan memanfaatkan informasi yang ada. Perancangan suatu peralatan kerja dengan berdasarkan data antropometri pemakainya bertujuan untuk mengurangi tingkat kelelahan kerja, meningkatkan performansi kerja dan meminimasi potensi kecelakaan kerja [9].

Antropometri berasal dari kata anthropos dan metros. Anthropos berarti manusia dan metricos berarti ukuran. Antropometri adalah ukuran-ukuran tubuh manusia secara alamiah baik dalam melakukan aktivitas statis (ukuran sebenarnya) maupun dinamis (disesuaikan dengan pekerjaan) [1].

Ergonomi adalah ilmu, seni, dan penerapan teknologi untuk menyerasikan atau menyeimbangkan antara segala fasilitas yang digunakan baik dalam beraktivitas maupun istirahat dengan segala kemampuan, kebolehan, dan keterbatasan manusia baik secara fisik maupun mental sehingga dicapai suatu kualitas hidup secara keseluruhan yang lebih baik [4].

Kelonggaran digunakan dalam suatu perancangan apabila diperlukan dan mempengaruhi produk yang akan dirancang. Kelonggaran dapat bervariasi tergantung pada musim, kondisi lingkungan, jenis kelamin, bahkan mode yang sedang berlaku. Dalam banyak kasus, memang berlaku penambahan ukuran untuk kelonggaran ini, namun pakaian dan perlengkapan lain yang sangat tebal justru dapat mengurangi pengukuran jangkauan dan rentang gerak sendi [6].

Value Engineering sebagai metode untuk meningkatkan nilai produk dengan meningkatkan hubungan antara fungsi produk dan biayanya. Definisi VE adalah suatu metoda yang sistematis untuk meningkatkan nilai dari jasa dan produk atau barang-barang dengan menggunakan suatu pengujian dari fungsi [11]. Tujuan dari Value Engineering adalah untuk mengukur nilai suatu produk (quality, performance, reliability). Pada tingkat biaya yang dapat diterima untuk mengeliminasi aspek yang tidak menambah nilai produk [5].

\section{METODE PENELITIAN}

Metodologi penelitian merupakan langkah penyelesaian masalah secara terencana dan sistematis. Adapun langkahlangkah yang dilakukan dalam penelitian pada gambar 1. 


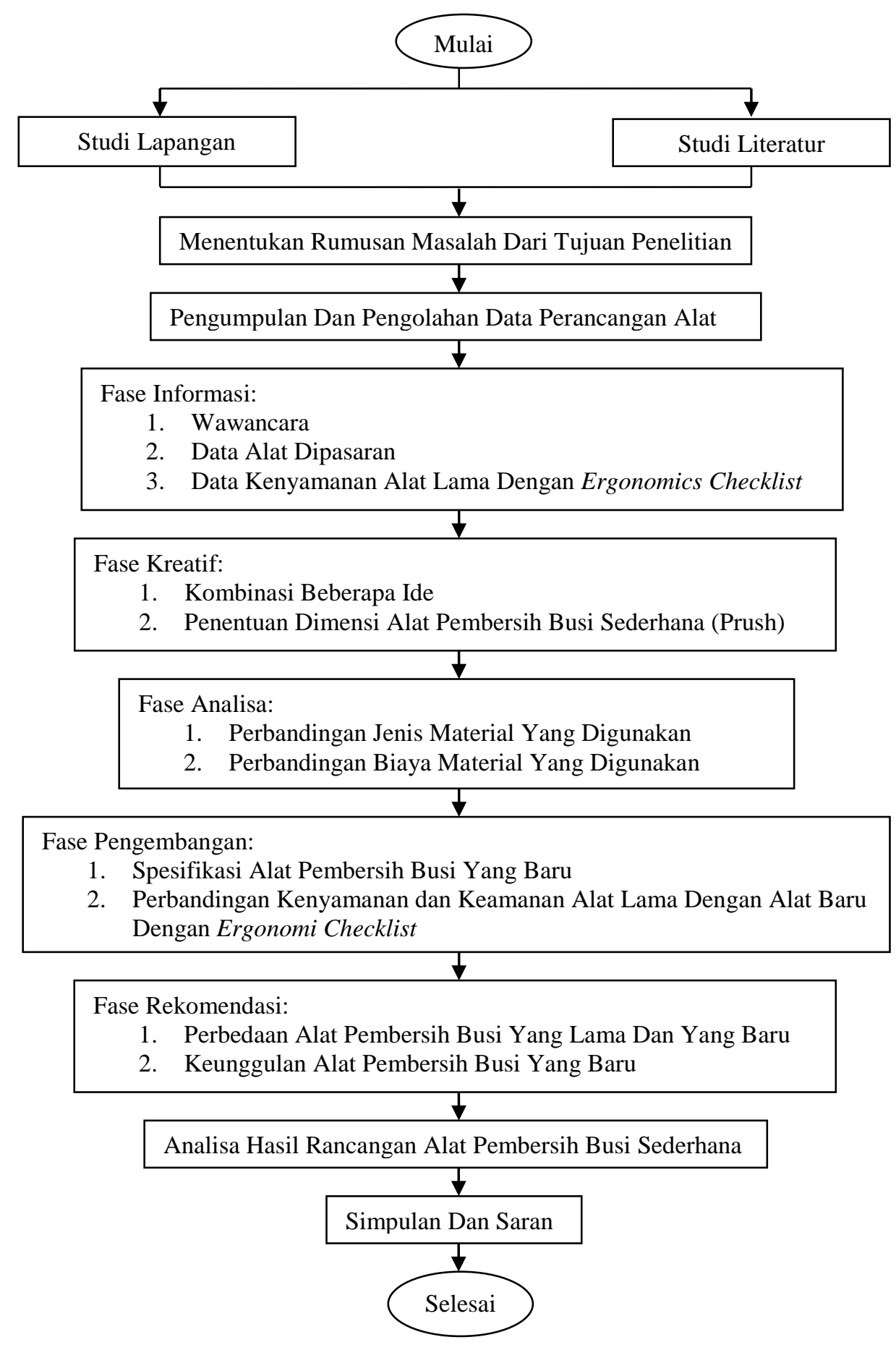

Gambar 1.Metodologi Penelitian

\section{HASIL DAN PEMBAHASAN}

Metode Value Engineering melalui beberapa tahap diantaranya [5]:

\subsection{Fase Informasi}

Pengambilan sampel dilakukan di UKM Bengkel Motor Koli Palembang dengan menggunakan metode wawancara dan Ergonomics checklist. Metode ini lebih akurat karena dilakukan langsung kepada mekanik di bengkel sehingga mendapatkan informasi yang baik. Dapat dilihat pada Tabel 1. 
Tabel 1. Ergonomics Checklist

\begin{tabular}{|c|c|c|c|c|}
\hline & & $\mathrm{Ya}$ & Tidak & Tindakan Yang Diambil \\
\hline Pegangan Busi & $\begin{array}{l}\text { Kenyamanan Memegang } \\
\text { Busi }\end{array}$ & & $\sqrt{ }$ & $\begin{array}{l}\text { Membuat Pegangan Busi } \\
\text { Dengan Sistem Ragum }\end{array}$ \\
\hline \multirow[t]{3}{*}{$\begin{array}{l}\text { Alat Pembersih } \\
\text { Busi Yang } \\
\text { Lama }\end{array}$} & $\begin{array}{l}\text { Kenyamanan Menggunakan } \\
\text { Alat }\end{array}$ & & $\sqrt{ }$ & $\begin{array}{l}\text { Membuat Alat Lebih } \\
\text { Nyaman dan Mudah } \\
\text { Digunakan }\end{array}$ \\
\hline & $\begin{array}{l}\text { Bentuk Alat Pembersih Busi } \\
\text { Ergonomi }\end{array}$ & & $\sqrt{ }$ & $\begin{array}{l}\text { Mendesain Alat Yang } \\
\text { Ergonomi }\end{array}$ \\
\hline & $\begin{array}{l}\text { Kelengkapan Perangkat } \\
\text { Pembersih Busi }\end{array}$ & & $\sqrt{ }$ & $\begin{array}{l}\text { Membuat Pegangan Busi } \\
\text { Dan Pembersihnya Menjadi } \\
\text { Satu }\end{array}$ \\
\hline \multirow[t]{2}{*}{ Tata Letak Alat } & Mudah Dipindahkan & & $\sqrt{ }$ & $\begin{array}{l}\text { Membuat Posisi Alat Bisa } \\
\text { Dipindahkan }\end{array}$ \\
\hline & $\begin{array}{l}\text { Kenyamanan Posisi } \\
\text { Pembersih dan Pegangan }\end{array}$ & & $\sqrt{ }$ & $\begin{array}{l}\text { Membuat Pembersih dan } \\
\text { Pegangan Dalam Satu Alat }\end{array}$ \\
\hline
\end{tabular}

Fase informasi terdapat beberapa tahap diantaranya:

\subsubsection{Data Mesin Dipasaran}

Untuk jenis alat yang ada di pasaran dapat dilihat pada Tabel 2.

Tabel 2. Produk Dipasaran

\begin{tabular}{|c|c|c|}
\hline \multirow[b]{2}{*}{ Deskripsi Produk } & Gerinda Duduk & Spark Plug Cleaner \\
\hline & & \\
\hline Harga & Rp1.100.000,00 - Rp3.700.000,00 & Rp.2.200.000,00 - Rp.6.400.000,00 \\
\hline Keutamaan & $\begin{array}{l}\text { Membersihkan busi atau } \\
\text { mengkikis material dengan putaran }\end{array}$ & Membersihkan dan uji coba busi \\
\hline Keunggulan & $\begin{array}{l}\text { Terdapat dua mata gerinda dan } \\
\text { bisa dirubah }\end{array}$ & Memiliki waktu yang singkat \\
\hline Kekurangan & $\begin{array}{l}\text { Daya litrik tinggi } \\
\text { Tidak memiliki pegangan pada } \\
\text { material } \\
\text { Alatnya sering bergeser }\end{array}$ & $\begin{array}{l}\text { Daya listrik tinggi } \\
\text { Harga alat mahal }\end{array}$ \\
\hline Komponen bahan & $\begin{array}{l}\text { Mata gerinda } \\
\text { Dinamo } \\
\text { Besi }\end{array}$ & $\begin{array}{l}\text { Tekanan air dan angin } \\
\text { Elektrik } \\
\text { Besi }\end{array}$ \\
\hline
\end{tabular}

\subsubsection{FAST}

Berikut ini adalah diagram FAST dari alat prush yang dapat dilihat pada Gambar 2.

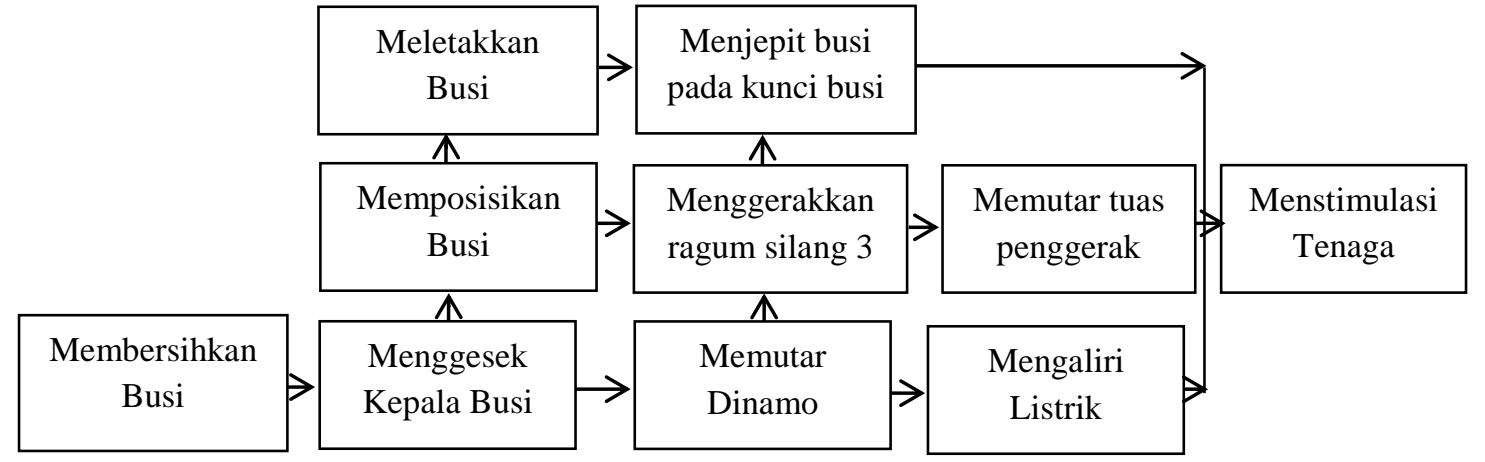

Gambar 2. Diagram FAST 


\subsection{Fase Kreatif}

Alat bantu untuk memunculkan ide-ide dengan menggunakan pernyataan yang terkait dengan permasalahan dan perancangan alat berdasarkan aspek $5 \mathrm{~W}$ dan $2 \mathrm{H}$, dapat dilihat pada Tabel 3 , nilai $5 \mathrm{~W}$ dan $2 \mathrm{H}$.

\subsubsection{Ide Orisinil}

Gambaran awal dalam membuat alat prush dapat dilihat pada Gambar 3.

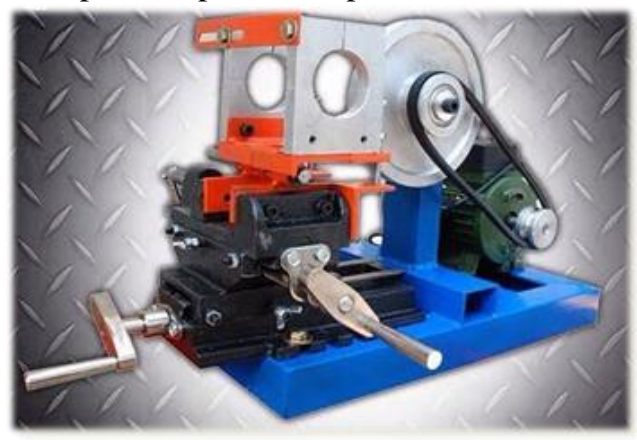

Gambar 3. Gambaran Awal Alat Prush

\begin{tabular}{|c|c|}
\hline \multicolumn{2}{|r|}{ Tabel 3. Tabel $5 \mathrm{~W}+2 \mathrm{H}$} \\
\hline $5 \mathrm{~W}+2 \mathrm{H}$ & $\begin{array}{c}\text { Keterangan } \\
\end{array}$ \\
\hline What & Merancang alat Prush (Pembesih Busi Sederhana) \\
\hline Who & Mekanik UKM Bengkel Motor Koli Palembang \\
\hline When & Ketika mekanik menerima service ringan \\
\hline Where & $\begin{array}{l}\text { UKM Bengkel Motor Koli Palembang pada proses } \\
\text { membersihkan busi }\end{array}$ \\
\hline Why & $\begin{array}{l}\text { Karena mekanik mengalamai beberapa keluhan } \\
\text { menggunakan alat yang lama }\end{array}$ \\
\hline How & $\begin{array}{l}\text { Mekanik Mengalami Keluhan Ketika Menggunakan Alat } \\
\text { Yang Lama, Selain itu juga alat lama menggunakan watt } \\
\text { yang besar yaitu } 375 \text { watt, maka dari iru dirancanglah alat } \\
\text { Prush (Pembersih Busi Sederhana) untuk mengurangi } \\
\text { keluhan mekanik dan mengurangi daya listrik yang } \\
\text { digunakan ketika melakukan proses membersihkan busi }\end{array}$ \\
\hline How Many & $\begin{array}{ll}\text { - } & \text { Material yang digunakan adalah besi siku, mata } \\
\text { gerinda kawat, baut full drat, dinamo mesin jahit, } \\
\text { dan plat. } \\
-\quad \text { Biaya untuk membuat alat prush hanya } \\
\text { Rp. } 480.000 \\
-\quad \begin{array}{l}\text { Daya listrik yang digunakan alat Prush hanya } 120 \\
\text { watt }\end{array}\end{array}$ \\
\hline
\end{tabular}

Ide-ide dan pemikiran dari hasil riset pasar dituang dalam beberapa desain alat prush. Pada Gambar 4, Gambar 5, dan Gambar 6 merupakan beberapa ide desain alat pembersih busi sederhana.

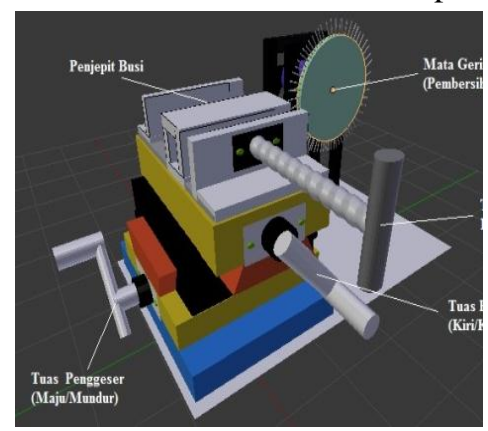

Gambar 4. Desain 1

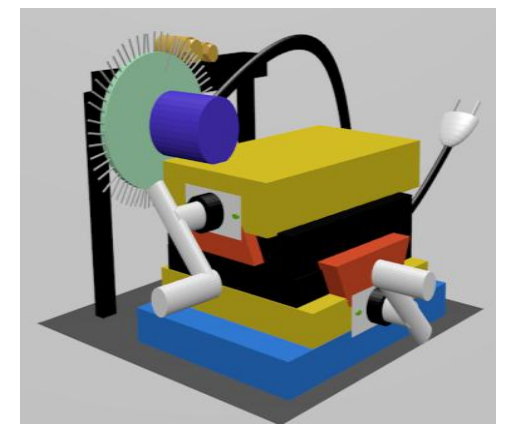

Gambar 5.Desain 2

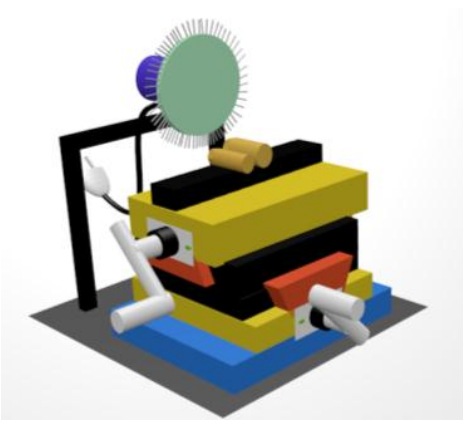

Gambar 6. Desain 3

Berdasarkan alat-alat pembersih busi sederhana yang ada dipasaran, dan dilatarbelakangi oleh kombinasi beberapa ide, di pilihlah desain nomor 3 (Gambar 6) dimana muncul ide orisinil dari perancangan alat pembersih busi sederhana yaitu penamaan alat "PRUSH". 


\subsubsection{Ukuran Alat Prush (Pembersih Busi Sederhana)}

Ukuran alat prush dapat dilihat pada Tabel 4.

Tabel 4. Dimensi Ragum Silang 3 Dipasaran

\begin{tabular}{|c|c|c|}
\hline No & Dimensi & Ukuran $(\mathrm{cm})$ \\
\hline 1 & Tinggi Ragum Silang 3 & $15 \mathrm{~cm}$ \\
\hline 2 & Lebar Ragum Silang 3 & $15 \mathrm{~cm}$ \\
\hline 3 & Tinggi Tuas Penggeser (Maju/Mundur) & $5 \mathrm{~cm}$ \\
\hline 4 & Tinggi Tuas Penggeser (Kiri/Kanan) & $10 \mathrm{~cm}$ \\
\hline 5 & Panjang Tuas Penggeser & $8 \mathrm{~cm}$ \\
\hline 6 & Tinggi Tuas Ragum & $15 \mathrm{~cm}$ \\
\hline
\end{tabular}

Pengukuran antropometri dapat dilihat pada Tabel 5.

Tabel 5. Pengukuran Antropometri

\begin{tabular}{|c|l|c|c|}
\hline \multirow{2}{*}{ No } & \multicolumn{1}{|c|}{ Data Antropometri } & Mekanik 1 & Mekanik 2 \\
\cline { 3 - 4 } & & Ukuran $(\mathrm{cm})$ & Ukuran $(\mathrm{cm})$ \\
\hline 1 & Panjang ibu jari & 6 & 5 \\
\hline 2 & Lebar ibu jari & 2,5 & 2,5 \\
\hline 3 & Diameter genggaman tangan (maksimal) & 5 & 4,5 \\
\hline 4 & Jarak dari meja operasi ke siku & 11 & 10 \\
\hline
\end{tabular}

\subsubsection{Dimensi Ukuran Alat}

Berikut ini merupakan rekapitulasi dimensi rancangan PRUSH yang dapat dilihat pada Gambar 7 dan Gambar 8.

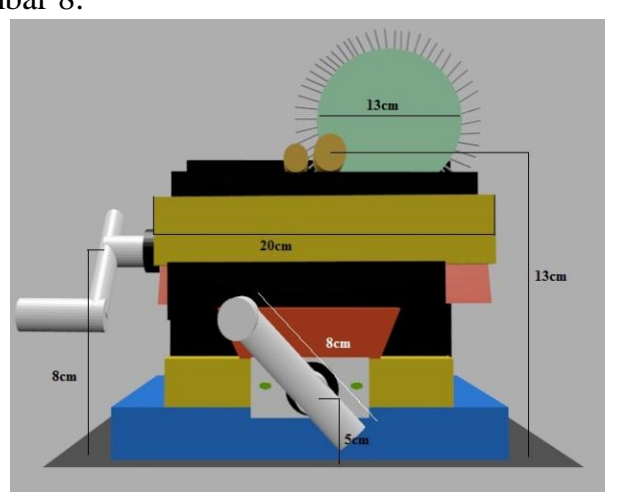

Gambar 7. Dimensi Alat Prush Tampak Depan

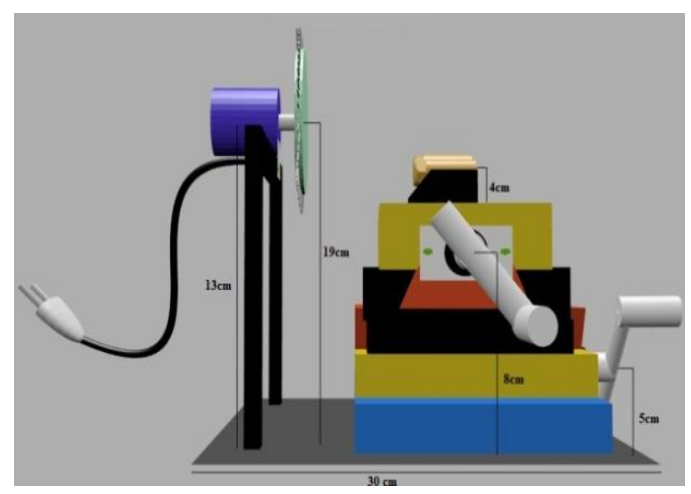

Gambar 8. Dimensi Alat Prush Tampak Samping

Rekapitulasi dimensi alat prush (pembersih busi sederhana) dapat dilihat pada Tabel 6.

Tabel 6. Rekapitulasi Dimensi Ukuran Alat Prush (Pembersih Busi Sederhana)

\begin{tabular}{|c|c|c|}
\hline No & Dimensi & Ukuran $(\mathrm{cm})$ \\
\hline 1 & Tinggi Ragum Silang 3 & $10 \mathrm{~cm}$ \\
\hline 2 & Lebar Ragum Silang 3 & $20 \mathrm{~cm}$ \\
\hline 3 & Tinggi Tuas Penggeser Busi (Maju/Mundur) & $5 \mathrm{~cm}$ \\
\hline 4 & Tinggi Tuas Penggeser Busi (Kiri/Kanan) & $8 \mathrm{~cm}$ \\
\hline 5 & Panjang Tuas & $8 \mathrm{~cm}$ \\
\hline 6 & Tinggi Penjepit Busi & $13 \mathrm{~cm}$ \\
\hline 7 & Tinggi Dudukan Dinamo & $13 \mathrm{~cm}$ \\
\hline 8 & Lebar Dudukan Dinamo & $22 \mathrm{~cm}$ \\
\hline 9 & Diameter Mata Gerinda & $13 \mathrm{~cm}$ \\
\hline 10 & Alas & $30 \mathrm{~cm} \mathrm{x} 24 \mathrm{~cm}$ \\
\hline
\end{tabular}

\subsubsection{Peta Proses Operasi Alat Prush (Pembersih Busi Sederhana)}

Peta Proses Operasi Alat Prush dapat dilihat pada Gambar 9.

\subsection{Fase Analisis}

\subsubsection{Gambar Rancangan Alat}


Berikut ini merupakan desain rancangan alat prush (pembersih busi sederhana) berdasarkan prespektifnya, dapat dilihat pada Gambar 10.

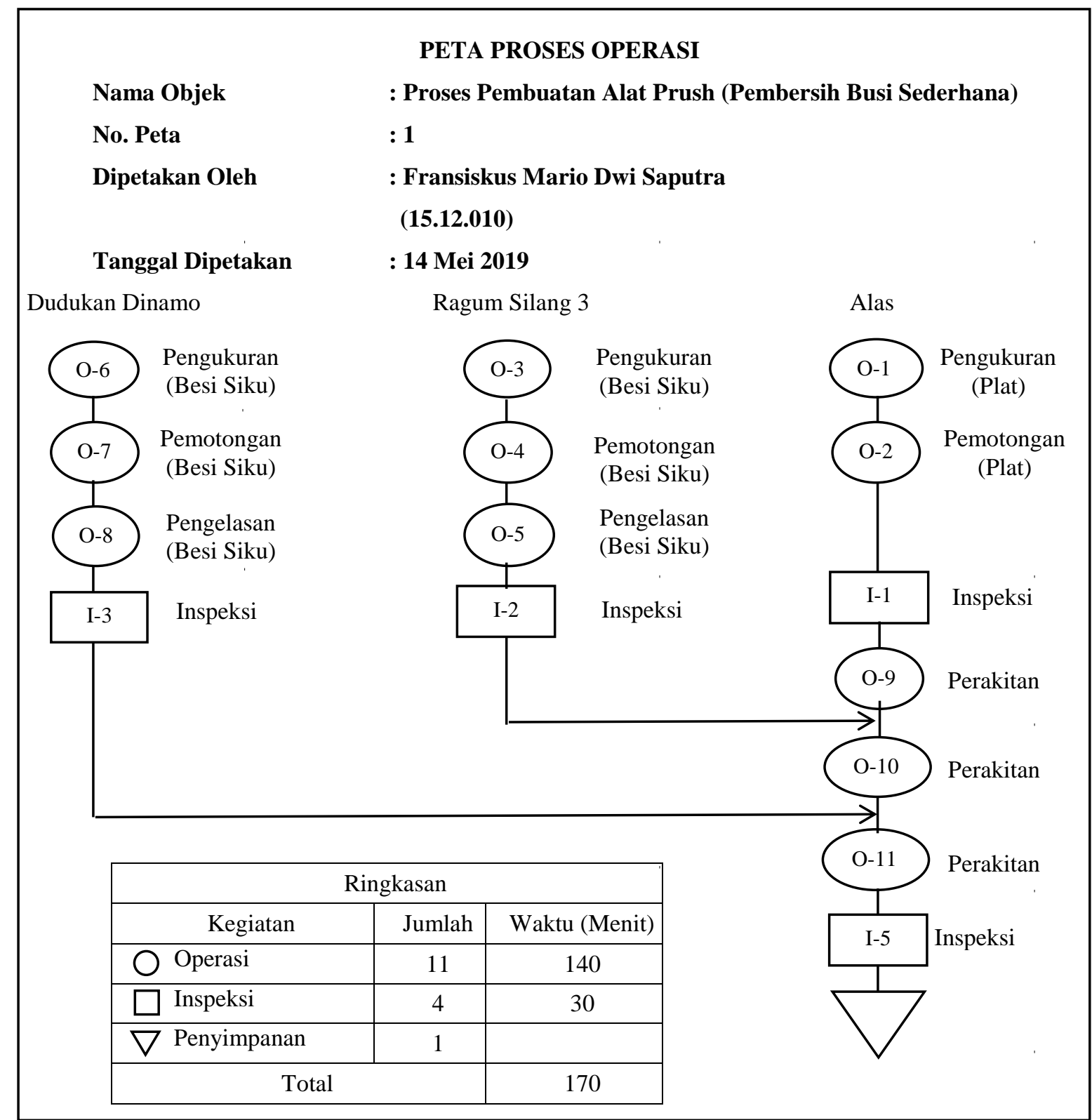

Gambar 9. Peta Proses Operasi 


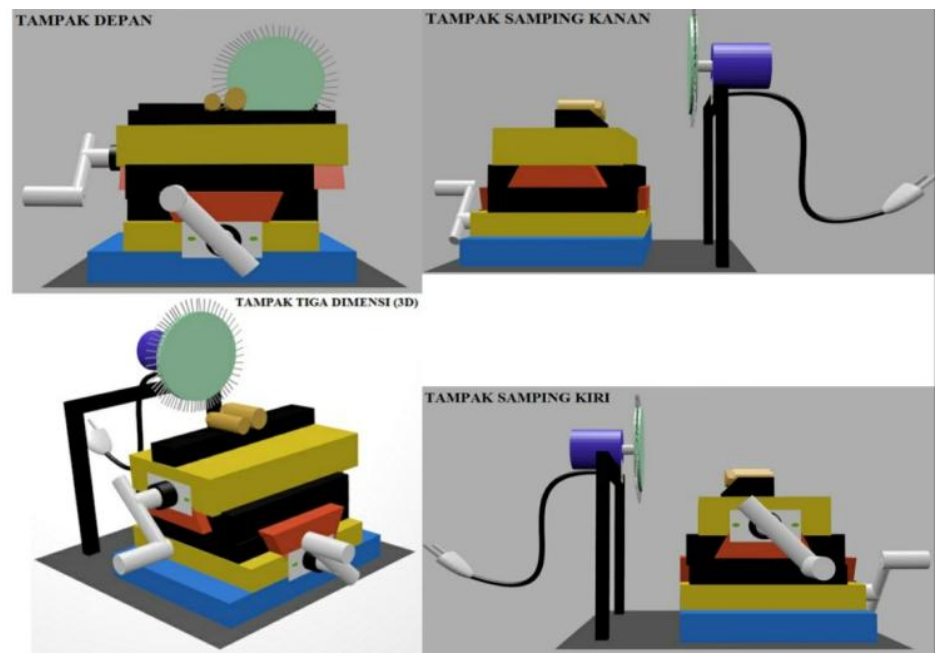

Gambar 10. Alat Prush Berdasarkan Prespektifnya

\subsubsection{Alternatif Material Yang Digunakan}

Alternatif material yang dapat dipergunakan untuk merancanga sebuah alat prush (pembersih busi sederhana) dapat dilihat pada Tabel 7.

Tabel 7. Alternatif Material

\begin{tabular}{|c|c|c|c|c|c|c|c|}
\hline \multirow[b]{2}{*}{$\begin{array}{c}\text { Alternatif } \\
\text { Material }\end{array}$} & \multicolumn{7}{|c|}{ Komponen } \\
\hline & $\begin{array}{l}\text { Rangka } \\
\text { Alat }\end{array}$ & $\begin{array}{l}\text { Penggerak } \\
\text { Busi }\end{array}$ & $\begin{array}{l}\text { Penjepit } \\
\text { Busi }\end{array}$ & $\begin{array}{l}\text { Pembersih } \\
\text { Busi }\end{array}$ & Dinamo & $\begin{array}{l}\text { Dudukan } \\
\text { Alat }\end{array}$ & $\begin{array}{l}\text { Dudukan } \\
\text { Dinamo }\end{array}$ \\
\hline 1 & $\begin{array}{l}\text { Plat } \\
\text { Besi }\end{array}$ & $\begin{array}{l}\text { Besi siku } \\
\text { dan baut } \\
\text { full drat }\end{array}$ & $\begin{array}{l}\text { Besi } \\
\text { siku }\end{array}$ & $\begin{array}{l}\text { Geinda } \\
\text { kawat }\end{array}$ & $\begin{array}{l}\text { Mesin } \\
\text { Jahit }\end{array}$ & Plat Besi & $\begin{array}{l}\text { Besi } \\
\text { Siku }\end{array}$ \\
\hline 2 & Baja & $\begin{array}{l}\text { Ragum } \\
\text { silang } 3\end{array}$ & Ragum & $\begin{array}{l}\text { Gerinda } \\
\text { Amplas }\end{array}$ & $\begin{array}{l}\text { Dinamo } \\
\text { Listrik }\end{array}$ & Baja & $\begin{array}{l}\text { Besi } \\
\text { Holo }\end{array}$ \\
\hline 3 & $\begin{array}{l}\text { Besi } \\
\text { Siku }\end{array}$ & $\begin{array}{l}\text { Ragum } \\
\text { silang } 3\end{array}$ & Ragum & $\begin{array}{l}\text { Gerinda } \\
\text { kawat }\end{array}$ & $\begin{array}{l}\text { Dinamo } \\
\text { Starter } \\
\text { Motor }\end{array}$ & Plat Besi & Plat besi \\
\hline
\end{tabular}

\subsubsection{Perbandingan Jenis Material Yang Digunakan}

Alternatif material alat prush (pembersih busi sederhana) beserta kelebihan dan kekurangan yang dimiliki pada material tersebut, dapat dilihat pada Tabel 8.

Tabel 8 Alternatif Material Beserta Kekurangan Dan Kelebihannya

\begin{tabular}{|c|c|c|c|c|c|c|c|c|c|}
\hline & \multicolumn{3}{|c|}{ Alternatif Pertama } & \multicolumn{3}{|c|}{ Alternatif Kedua } & \multicolumn{3}{|c|}{ Alternatif Ketiga } \\
\hline Komponen & Material & Kelebihan & Kekurangan & Material & Kelebihan & Kekurangan & Material & Kelebihan & Kekurangan \\
\hline $\begin{array}{l}\text { Rangka } \\
\text { Alat }\end{array}$ & Plat besi & $\begin{array}{l}\text { - murah } \\
\text { - ringan }\end{array}$ & $\begin{array}{l}\text { - tidak kuat } \\
\text { terhadap } \\
\text { korosi }\end{array}$ & Baja & $\begin{array}{l}\text { - kuat } \\
\text { - tahan } \\
\text { lama }\end{array}$ & $\begin{array}{l}\text { - mahal } \\
\text { - berat }\end{array}$ & $\begin{array}{l}\text { Besi } \\
\text { siku }\end{array}$ & - murah & $\begin{array}{l}\text { - tidak kuat } \\
\text { terhadap } \\
\text { korosi }\end{array}$ \\
\hline $\begin{array}{l}\text { Penggerak } \\
\text { Busi }\end{array}$ & $\begin{array}{l}\text { Besi } \\
\text { siku dan } \\
\text { baut full } \\
\text { drat }\end{array}$ & - murah & $\begin{array}{l}\text { - pembuatan } \\
\text { sedikit susah }\end{array}$ & $\begin{array}{l}\text { Ragum } \\
\text { silang } 3\end{array}$ & $\begin{array}{l}\text { - mudah } \\
\text { digunakan }\end{array}$ & $\begin{array}{l}\text { - mahal } \\
\text { - berat }\end{array}$ & $\begin{array}{l}\text { Ragum } \\
\text { silang } 3\end{array}$ & $\begin{array}{l}\text { - mudah } \\
\text { digunakan }\end{array}$ & $\begin{array}{l}\text { - mahal } \\
\text { - berat }\end{array}$ \\
\hline $\begin{array}{l}\text { Penjepit } \\
\text { Busi }\end{array}$ & $\begin{array}{l}\text { Kunci } \\
\text { busi }\end{array}$ & - kuat & $\begin{array}{l}\text { - tidak kuat } \\
\text { terhadap } \\
\text { korosi }\end{array}$ & Ragum & - kuat & - mahal & Ragum & - kuat & - mahal \\
\hline $\begin{array}{l}\text { Pembersih } \\
\text { Busi }\end{array}$ & $\begin{array}{l}\text { Gerinda } \\
\text { kawat }\end{array}$ & - detail & -percikan api & $\begin{array}{l}\text { Gerinda } \\
\text { amplas }\end{array}$ & - murah & - tidak detail & $\begin{array}{l}\text { Gerinda } \\
\text { kawat }\end{array}$ & - detail & $\begin{array}{l}\text { - percikan } \\
\text { api }\end{array}$ \\
\hline Dinamo & $\begin{array}{l}\text { Mesin } \\
\text { jahit }\end{array}$ & $\begin{array}{l}\text { - daya } \\
\text { rendah }\end{array}$ & $\begin{array}{l}\text { - sulit } \\
\text { mencari } \\
\text { barangnya }\end{array}$ & $\begin{array}{l}\text { Dinamo } \\
\text { listrik }\end{array}$ & $\begin{array}{l}\text { - rotasi } \\
\text { cepat }\end{array}$ & $\begin{array}{l}\text { - berat } \\
\text { - daya listrik } \\
\text { tinggi }\end{array}$ & $\begin{array}{l}\text { Dinamo } \\
\text { starter } \\
\text { motor }\end{array}$ & $\begin{array}{l}\text { - rotasi } \\
\text { cepat }\end{array}$ & $\begin{array}{l}\text { - daya listrik } \\
\text { tinggi }\end{array}$ \\
\hline $\begin{array}{l}\text { Dudukan } \\
\text { Alat }\end{array}$ & Plat besi & $\begin{array}{l}\text { - murah } \\
\text { - ringan }\end{array}$ & $\begin{array}{l}\text { - tidak kuat } \\
\text { terhadap } \\
\text { korosi }\end{array}$ & Baja & $\begin{array}{l}\text { - kuat } \\
\text { - tahan } \\
\text { lama }\end{array}$ & $\begin{array}{l}\text { - mahal } \\
\text { - berat }\end{array}$ & Plat besi & $\begin{array}{l}\text { - murah } \\
\text { - ringan }\end{array}$ & $\begin{array}{l}\text { - tidak kuat } \\
\text { terhadap } \\
\text { korosi }\end{array}$ \\
\hline $\begin{array}{l}\text { Dudukan } \\
\text { Dinamo }\end{array}$ & $\begin{array}{l}\text { Besi } \\
\text { holo }\end{array}$ & - murah & $\begin{array}{l}\text { - tidak kuat } \\
\text { terhadap } \\
\text { korosi }\end{array}$ & $\begin{array}{l}\text { Besi } \\
\text { siku }\end{array}$ & - murah & $\begin{array}{l}\text { - tidak kuat } \\
\text { terhadap } \\
\text { korosi }\end{array}$ & Plat besi & $\begin{array}{l}\text { - murah } \\
\text { - ringan }\end{array}$ & $\begin{array}{l}\text { - tidak kuat } \\
\text { terhadap } \\
\text { korosi }\end{array}$ \\
\hline
\end{tabular}




\subsubsection{Perbandingan Biaya Material Yang Digunakan}

Biaya pada alternatif material yang digunakan dapat dilihat pada Tabel 9.

\subsection{Fase Pengembangan}

\subsubsection{Perbandingan Alat Pembersih Busi Yang Baru Dan Yang Lama}

Pada alat pembersih busi yang lama, proses pembersihan busi dilakukan dengan memegang busi dengan tangan kosong, kemudian mendekatkan kepala busi ke mata gerinda kawat pada gerinda duduk yang sudah menyala. Gambar ala pembersih busi yang lama dapat dilihat pada Gambar 11.

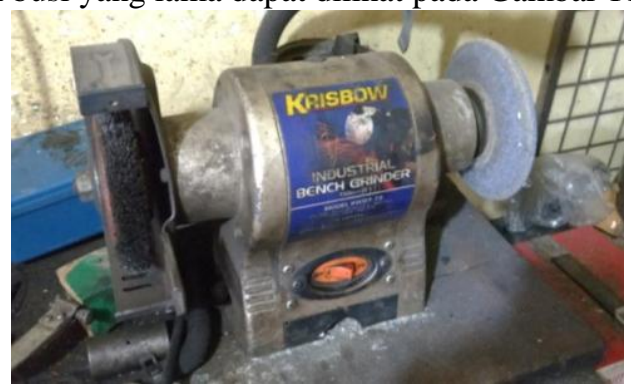

Gambar 11. Alat Pembersih Busi Yang Saat Ini Digunakan Tabel 9. Biaya Alternatif Material

\begin{tabular}{|c|c|c|c|c|c|c|c|}
\hline \multirow{2}{*}{ No } & \multirow{2}{*}{ Komponen } & \multicolumn{2}{|c|}{ Alternatif Pertama } & \multicolumn{2}{|c|}{ Alternatif Kedua } & \multicolumn{2}{|c|}{ Alternatif Ketiga } \\
\hline & & Material & Biaya & Material & Biaya & Material & Biaya \\
\hline 1 & Rangka Alat & Plat besi & Rp 25.000 & Baja & Rp 50.000 & Besi siku & Rp 40.000 \\
\hline 2 & $\begin{array}{l}\text { Penggerak } \\
\text { Busi }\end{array}$ & $\begin{array}{l}\text { Besi siku } \\
\text { dan baut } \\
\text { full drat }\end{array}$ & Rp 150.000 & $\begin{array}{l}\text { Ragum } \\
\text { silang } 3\end{array}$ & Rp 450.000 & $\begin{array}{l}\text { Ragum } \\
\text { silang } 3\end{array}$ & Rp 450.000 \\
\hline 3 & $\begin{array}{l}\text { Penjepit } \\
\text { Busi }\end{array}$ & Kunci busi & Rp 40.000 & Ragum & Rp 150.000 & Ragum & Rp 150.000 \\
\hline 4 & $\begin{array}{l}\text { Pembersih } \\
\text { Busi }\end{array}$ & $\begin{array}{l}\text { Gerinda } \\
\text { kawat }\end{array}$ & Rp 100.000 & $\begin{array}{l}\text { Gerinda } \\
\text { amplas }\end{array}$ & Rp 70.000 & $\begin{array}{l}\text { Gerinda } \\
\text { kawat }\end{array}$ & Rp 100.000 \\
\hline 5 & Dinamo & $\begin{array}{l}\text { Dinamo } \\
\text { mesin jahit }\end{array}$ & Rp 100.000 & $\begin{array}{l}\text { Dinamo } \\
\text { listrik }\end{array}$ & Rp 250.000 & $\begin{array}{l}\text { Dinamo } \\
\text { starter }\end{array}$ & Rp 150.000 \\
\hline 6 & $\begin{array}{l}\text { Dudukan } \\
\text { Alat }\end{array}$ & Plat besi & Rp 25.000 & Baja & Rp 50.000 & Plat besi & Rp 25.000 \\
\hline 7 & $\begin{array}{l}\text { Dudukan } \\
\text { Dinamo }\end{array}$ & Besi holo & Rp 40.000 & $\begin{array}{l}\text { Besi } \\
\text { siku }\end{array}$ & Rp 30.000 & Plat besi & Rp 25.000 \\
\hline \multicolumn{3}{|c|}{ Total biaya } & Rp 480.000 & & $\operatorname{Rp} 1.050 .000$ & & Rp 940.000 \\
\hline
\end{tabular}

\subsubsection{Spesifikasi Alat Pembersih Busi Sederhana (Prush)}

Beberapa spesifikasi yang dimiliki oleh alat prush (pembersih busi sederhana), dapat dilihat pada Tabel 10. Tabel 10. Spesifikasi Alat Prush (Pembersih Busi Sederhana)

\begin{tabular}{|c|c|c|}
\hline No. & Tujuan & Kriteria \\
\hline 1. & Aman Digunakan & $\begin{array}{c}\text { Tidak terkena percikan api } \\
\text { Tangan tidak merasakan panas }\end{array}$ \\
\hline 2. & Tahan Lama & $\begin{array}{c}\text { Kuat } \\
\text { Tidak mudah rusak } \\
\text { Tidak mudah korosi }\end{array}$ \\
\hline 3. & Mudah Digunakan & $\begin{array}{c}\text { Mudah dipindahkan } \\
\text { Mudah dibersihkan }\end{array}$ \\
\hline 4. & Nyaman & Tidak menggunakan tenaga berlebih \\
\hline 5. & Hemat & Daya listrik yang dikeluarkan 120 watt \\
\hline
\end{tabular}

\subsubsection{Perbandingan Kenyamanan}

Perbandingan kenyamanan pada proses membersihkan busi dapat dilihat pada perbandingan hasil ergonomics checklist (dengan pertanyaan yang sama) dari mekanik, dapat dilihat pada Tabel 11.

\subsection{Fase Rekomendasi}

3.5.1 Perbedaan Alat Pembersih Busi Yang Lama Dan Yang Baru 
Proses pembersihan busi dilakukan dengan memegang busi dengan tangan kosong, kemudian mendekatkan kepala busi ke mata gerinda kawat pada gerinda duduk yang sudah menyala, sedangkan pada alat prush (pembersih busi sederhana) mekanik hanya menaruhkan busi ke penjepit busi, kemudian arahkan busi dengan penggerak busi agar kepala busi mengenai mata gerinda kawat yang telah berputar. Alat pembersih busi yang lama dapat dilihat pada Gambar 12.

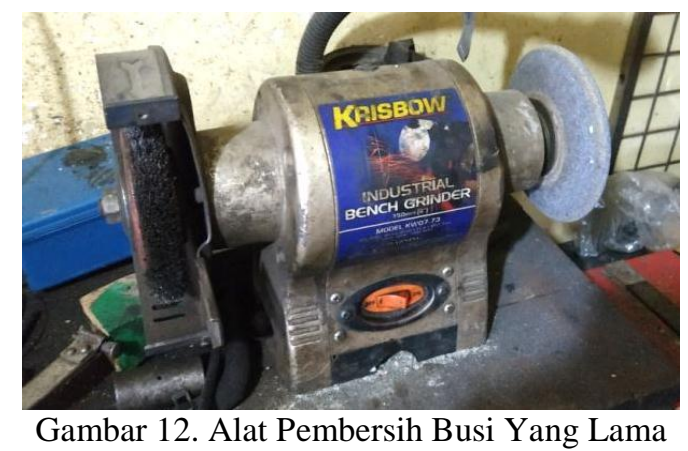

Tabel 11. Kenyamanan Menggunkan Alat Pembersih Busi Yang Lama dan Alat Prush

\begin{tabular}{|c|c|c|c|c|c|c|c|}
\hline \multirow[b]{2}{*}{ Material } & \multirow[b]{2}{*}{ Ergonomis } & \multicolumn{3}{|c|}{ Menggunakan Alat Lama } & \multicolumn{3}{|c|}{ Menggunakan Alat Baru } \\
\hline & & $\mathrm{Ya}$ & Tidak & $\begin{array}{c}\text { Tindakan } \\
\text { Yang } \\
\text { Diambil }\end{array}$ & $\mathrm{Ya}$ & Tidak & $\begin{array}{c}\text { Tindakan } \\
\text { Yang } \\
\text { Diambil }\end{array}$ \\
\hline $\begin{array}{l}\text { Pegangan } \\
\text { Busi }\end{array}$ & $\begin{array}{l}\text { Kenyamanan } \\
\text { Memegang } \\
\text { Busi }\end{array}$ & & $\sqrt{ }$ & $\begin{array}{l}\text { Membuat } \\
\text { Pegangan } \\
\text { Busi Dengan } \\
\text { Sistem } \\
\text { Ragum }\end{array}$ & $\sqrt{ }$ & & $\begin{array}{l}\text { Telah Dibuat } \\
\text { Pegangan } \\
\text { Busi Dengan } \\
\text { Sistem } \\
\text { Ragum }\end{array}$ \\
\hline \multirow{3}{*}{$\begin{array}{l}\text { Alat } \\
\text { Pembersih } \\
\text { Busi } \\
\text { Yang } \\
\text { Lama }\end{array}$} & $\begin{array}{l}\text { Kenyamanan } \\
\text { Menggunakan } \\
\text { Alat }\end{array}$ & & $\sqrt{ }$ & $\begin{array}{l}\text { Membuat } \\
\text { Alat Lebih } \\
\text { Nyaman dan } \\
\text { Mudah } \\
\text { Digunakan }\end{array}$ & $\sqrt{ }$ & & $\begin{array}{l}\text { Telah Dibuat } \\
\text { Alat Lebih } \\
\text { Nyaman dan } \\
\text { Mudah } \\
\text { Digunakan }\end{array}$ \\
\hline & $\begin{array}{l}\text { Bentuk Alat } \\
\text { Pembersih } \\
\text { Busi Ergonomi }\end{array}$ & & $\sqrt{ }$ & $\begin{array}{l}\text { Mendesain } \\
\text { Alat Yang } \\
\text { Ergonomi }\end{array}$ & $\sqrt{ }$ & & $\begin{array}{l}\text { Telah } \\
\text { Didesain Alat } \\
\text { Yang } \\
\text { Ergonomi }\end{array}$ \\
\hline & $\begin{array}{l}\text { Kelengkapan } \\
\text { Perangkat } \\
\text { Pembersih } \\
\text { Busi }\end{array}$ & & $\sqrt{ }$ & $\begin{array}{l}\text { Membuat } \\
\text { Pegangan } \\
\text { Busi Dan } \\
\text { Pembersihnya } \\
\text { Menjadi Satu }\end{array}$ & $\sqrt{ }$ & & $\begin{array}{l}\text { Telah Dibuat } \\
\text { Pegangan } \\
\text { Busi Dan } \\
\text { Pembersihnya } \\
\text { Menjadi Satu }\end{array}$ \\
\hline \multirow{2}{*}{$\begin{array}{l}\text { Tata } \\
\text { Letak } \\
\text { Alat }\end{array}$} & $\begin{array}{l}\text { Mudah } \\
\text { Dipindahkan }\end{array}$ & & $\sqrt{ }$ & $\begin{array}{l}\text { Membuat } \\
\text { Posisi Alat } \\
\text { Bisa } \\
\text { Dipindahkan }\end{array}$ & $\sqrt{ }$ & & $\begin{array}{l}\text { Telah Dibuat } \\
\text { Posisi Alat } \\
\text { Bisa } \\
\text { Dipindahkan }\end{array}$ \\
\hline & $\begin{array}{l}\text { Kenyamanan } \\
\text { Posisi } \\
\text { Pembersih dan } \\
\text { Pegangan }\end{array}$ & & $\sqrt{ }$ & $\begin{array}{l}\text { Membuat } \\
\text { Pembersih } \\
\text { dan Pegangan } \\
\text { Dalam Satu } \\
\text { Alat }\end{array}$ & $\sqrt{ }$ & & $\begin{array}{l}\text { Telah Dibuat } \\
\text { Pembersih } \\
\text { dan Pegangan } \\
\text { Dalam Satu } \\
\text { Alat }\end{array}$ \\
\hline
\end{tabular}

Alat prush menambahkan pegangan pada busi ketika akan melakukan pembersihan busi yang membuat mekanik lebih mudah dan mengurangi resiko terjadinya keluhan yang dialami pada penggunaan alat yang lama, sehingga kenyamanan mekanik dapat meningkat serta keluhan mekanik dapat berkurang. Alat prush lebih baik dikarenakan tambahan pemegang busi yang kuat karena menggunakan penjepit dengan sistem click sehingga mekanik tidak perlu susah untuk memegangnya dan mekanik dapat dengan mudah untuk 
menggeser bagian - bagian busi yang akan dibersihkan. Alat pembersih busi sederhana (Prush) dapat dilihat pada Gambar 13.

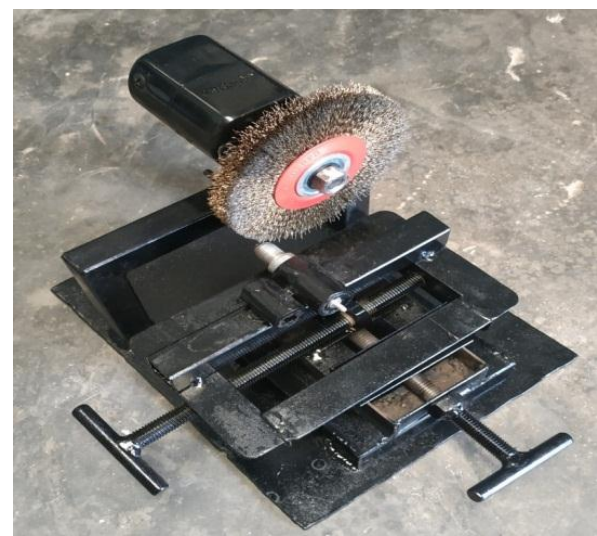

Gambar 13. Alat Pembersih Busi Sederhana (Prush)

Perbandingan daya listrik yang digunakan alat lama dan alat prush dapat dilihat pada Tabel 12.

Tabel 12. Perbandingan Daya Listrik Yang Digunakan

\begin{tabular}{|c|c|}
\hline Alat Lama & Alat Prush \\
\hline 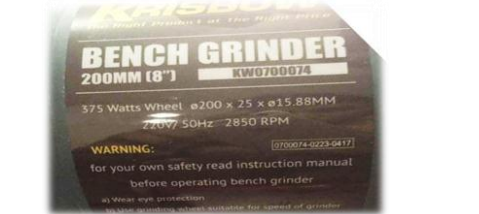 & 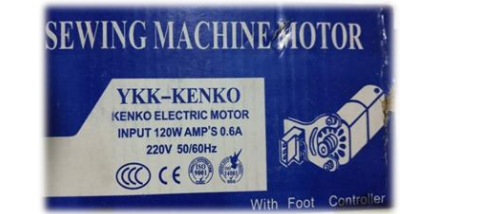 \\
\hline $\begin{array}{ll}- & 375 \mathrm{Watt} \\
- & 2850 \mathrm{RPM} \\
- & \text { Waktu pengerjaan } 1,8 \text { menit }\end{array}$ & $\begin{array}{ll}- & 120 \text { Watt } \\
- & 7500 \text { RPM } \\
- & \text { Waktu pengerjaan 2,3 menit }\end{array}$ \\
\hline
\end{tabular}

Perbandingan hasil kebersihan dari alat lama dan alat prush dapat dilihat pada Tabel 14.

Tabel 14. Perbandingan Hasil Kebersihan Alat Lama dan Alat Prush

\begin{tabular}{|c|c|c|}
\hline \multicolumn{2}{|c|}{ Hasil Alat Lama } & \multirow{2}{*}{ Keterangan } \\
\hline Sebelum & Sesudah & \\
\hline & & $\begin{array}{ll}\text { - } & \text { Bagian kepala busi bersih. } \\
\text { - } & \text { Tidak ada kotoran yang } \\
& \text { menutupi bagian pembakaran. }\end{array}$ \\
\hline \multicolumn{2}{|c|}{ Hasil Alat Baru } & \multirow{2}{*}{ Keterangan } \\
\hline Sebelum & Sesudah & \\
\hline & & $\begin{array}{ll}\text { - } & \text { Bagian kepala busi bersih. } \\
\text { - } & \text { Tidak ada kotoran yang } \\
& \text { menutupi bagian pembakaran. }\end{array}$ \\
\hline
\end{tabular}

\subsubsection{Ergonomi}

\subsubsection{Ergonomi}

Ergonomi proses pembersihan busi dengan alat pembersih busi yang lama dan alat pembersih busi sederhana (prush), dapat dilihat pada Gambar 14 dan Gambar 15.
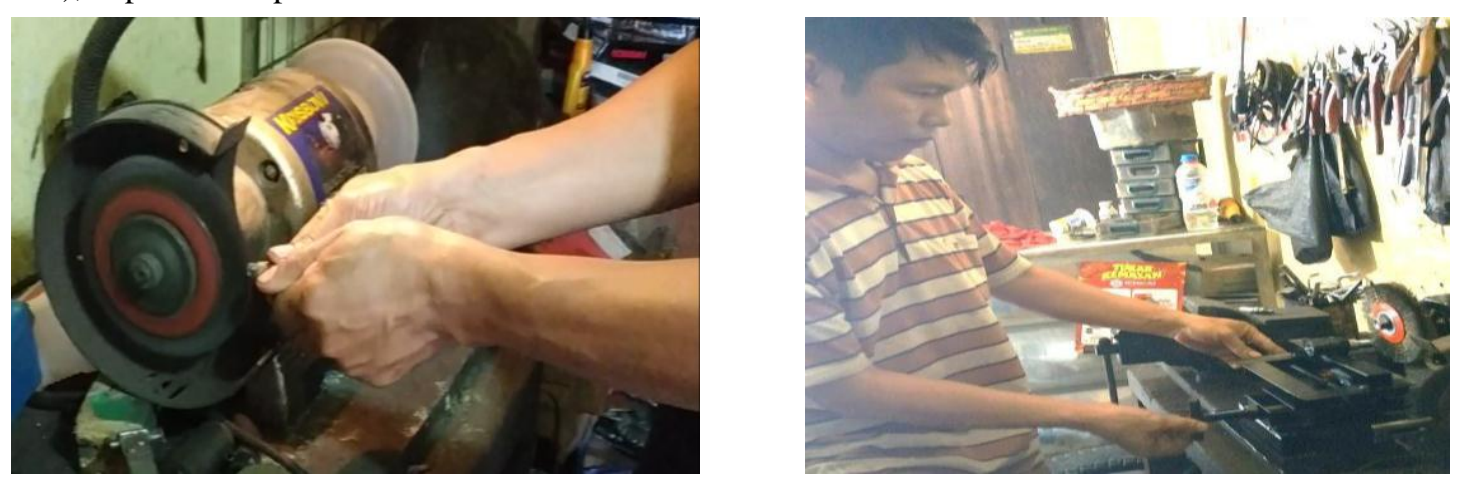


\subsubsection{Keselamatan Kerja}

Ketika melakukan proses membersihkan busi dengan alat yang lama, mekanik memegang busi tersebut dengan tangan kosong sehingga hal-hal yang memicu keluhan tersebut dapat terjadi. Dengan alat prush, busi yang biasanya dipegang dengan tangan kosong akan dirubah dengan adanya penjepit busi dengan sistem click sehingga mekanik tidak akan mengalami busi yang terlepas dan busi yang panas ketika dipegang.

\subsubsection{Kesehatan Kerja}

Pada alat yang lama, mekanik perlu memegang busi untuk melakukan pembersihan busi. Dengan alat prush, busi yang biasanya dipegang atau digenggam dengan tangan kosong oleh mekanik tidak perlu dilakukan lagi untuk proses membesihkan busi tersebut, karena telah disediakan alat penjepit untuk busi tersebut dengan sistem click.

\section{SIMPULAN}

Berdasarkan pengolahan data dan analisis yang telah dilakukan di UKM Bengkel Motor Koli Palembang dapat disimpulkan bahwa Berdasarkan pengolahan data dan analisis yang telah dilakukan di UKM Bengkel Motor Koli Palembang dapat disimpulkan Hasil rancangan alat prush (pembersih busi sederhana) yang berfungsi untuk membersihkan busi dengan ukuran dimensi tinggi ragum silang tiga $10 \mathrm{~cm}$, lebar ragum silang tiga $20 \mathrm{~cm}$, tinggi tuas penggeser busi (maju/mundur) $5 \mathrm{~cm}$, tinggi tuas penggeser busi (kiri/kanan) 8 $\mathrm{cm}$, panjang tuas $8 \mathrm{~cm}$, tinggi penjepit busi $13 \mathrm{~cm}$, tinggi dudukan dinamo $13 \mathrm{~cm}$, lebar dudukan dinamo 22 $\mathrm{cm}$, diameter mata gerinda $13 \mathrm{~cm}$, dan lebar alas $30 \mathrm{~cm}$ x $24 \mathrm{~cm}$, dapat dilihat pada Gambar 21, dengan biaya Rp.480.000,00. Kenyamanan meningkat 100\% setelah menggunakan alat prush, dapat dilihat pada Ergonomics Checklist kedua alat, dimana ketidaknyamanan mekanik ketika menggunakan alat lama menjadi nyaman ketika menggunakan alat prush. Daya listrik yang digunakan pada alat lama sebesar 375 watt telah berkurang menjadi 120 watt dengan alat prush (terjadi penurunan sebesar 68\%), dapat dilihat pada Tabel 14 .

\section{DAFTAR PUSTAKA}

[1] Arini. Firlia Ayu, 2010. Pengukuran Antropometri dan Hubungannya Dengan Golden Standard Persen Lemak Tubuh, Bioelectrical Impedance Analysis: Studi Validasi Pada Anak Sekolah Dasar. Universitas Indonesia.

[2] Kurniawati. Ita, 2009. Tinjauan Faktor Resiko Ergonomi dan Keluhan Subjektif Terhadap Terjadinya Gangguan Muskuloskeletal Pada Pekerja Pabrik Proses Finishing di Departemen PPC PT Southern Cross Texttile Industri Ciracas Jakarta Timur. Universitas Indonesia.

[3] Priyo, Mandiyo. 2010. Aplikasi Value Engineering pada proyek Kontruksi (Studi Kasus: Pembangunan Gedung BPKP Yogyakarta).

[4] Raharjo. Poppy, 2008. Usulan Perancangan Alat Pemotong Karton (Studi Kasus di D\&D Handycraft Collections). Universitas Atma Jaya Yogyakarta.

[5] Suryawidayat, Y.Wahyu. 2011. Pengembangan Produk Komponen Cylinder Head Dengan Pendekatan Quality Function Deployment dan Value Analysis. Universitas Indonesia

[6] Wibowo, Levin. 2017. Penerapan Value Engineering Pada Proyek Kontruksi (Studi Kasus: Proyek Pembangunan Rumah Sakit di Kota Sragen). 